\title{
ENHANCING EFFICIENCY OF HUMAN RESOURCES SERVICES IN GOVERNMENT AGENCIES OF KAZAKHSTAN*
}

\author{
Alma Kuljambekova \\ Academy of Public Administration under the President of the Republic of Kazakhstan \\ Astana, Kazakhstan, str. Abaja 33 «a» \\ doi:10.13165/VPA-13-12-4-10
}

\begin{abstract}
New objectives of human resources (hereinafter - HR) services include the implementation of HR policy and coordination of HR management in a government agency. Therefore, responsibilities of HR services are starting to embrace a wider range of activities, including development of labour motivation systems, management of professional promotion and diagnostic method of auditing in HR management in a government agency.

Enhancing efficiency of government agencies, quality of public services they deliver and implementation of state functions have become the key focus of all broad reforms in the civil service in the Republic of Kazakhstan. The effectiveness of reforms depends on the combination of various factors and conditions. The organization in charge of locally implementing reforms is the HR service, which is one of the key links in managing and providing effective and innovative activities of a government agency.
\end{abstract}

Keywords: efficiency, human resources service, government agencies.

Raktažodžiai: efektyvumas, žmoniu ištekliu tarnyba, valstybinès ịstaigos.

\section{Introduction}

The Strategic Development Plan of Kazakhstan, 2020 sets the task to further reform civil service by enhancing its efficiency, which is achieved by improving training system for civil servants, enhancing prestige of civil service and improving HR management in

* This article is part of the electronic conference: „Public Administration in Central Europe: In Search of Tradition“ organized by the Institute of Public Administration at Mykolas Romeris University (Vilnius, Lithuania) in partnership with the Academic Association of Management and Administration (Lithuania) on November 6th and 7th, 2013. 
civil service [1]. In this regard, the main purposes of the Concept of Civil Service New Model in the Republic of Kazakhstan (hereinafter - the Concept) include forming a new HR policy and effective system of HR management in public sector, improving the quality of public services delivery that is a government agencies' performance indicator, and improving ethic norms and creating a positive image of civil service $[2,5,6]$.

\section{The main areas of focus of HR service in government agencies of Kazakhstan}

Reforming the civil service involves reforms in the systems of civil service organization and HR management. Civil service organization embraces the issues of defining ranks, positions and responsibilities for each position, civil service admission and selection rules, service affiliation and termination, etc., while HR management is a part of government agency's strategy, which is comprised of task-oriented and comprehensive provision of an organization with all necessary staff and creating favourable social and psychological climate for their productive work.

The modern practice of the civil service in Kazakhstan does not have methodology of developing and creating an effective system of HR management.

Insufficiency of managing powers and functions of HR service along with unavailable efficient HR managerial staff is the main reason of its low status.

Despite the fact that there are certain results in forming an effective system of professional civil service, as it is clear from the objectives set, one of the priorities for Kazakhstan is the formation of an effective system of HR management in civil service. It is the HR service that is to play a major role in the system of HR management of the state apparatus.

The state apparatus of Kazakhstan is represented by government agencies, a total of which is divided into central and local level agencies in accordance with three branches of power. All in all, there are over 91000 employees in civil service, among them 3,6\% belong to the category of political servants and $96,4 \%$ - to administrative civil servants [3].

According to the Presidential Decree of December 29, 1999, №318 'On approving the Register of administrative civil servants' positions and List of categories of administrative civil service positions', positions of administrative civil servants are divided into 'A-E' categories. The 'A-C' categories represent central government agencies, whereas the 'D-E' categories are local government agencies.

The domestic research in civil service has shown that, firstly, the proportion of civil servants to the total population is $0,6 \%$ and to the total number of the employed - slightly over $1 \%$. These indicators are considerably lower than those of most foreign countries. However, it can be stated that the functions of the state apparatus have been indeed reduced to a minimum, despite the fact that there are no universal calculation methods and standards for civil servants' staff size in the world practice. Secondly, the HR management in civil service has a strong informal tendency for $10 \%$ and $60 \%$ female representation in political and administrative civil services, respectively. Thirdly, age proportions of civil servants 
are well-balanced with young employees naturally prevailing in positions of experts and specialists. Fourthly, civil service is rather stable in terms of human resources, which is proved by an average employment term (for political state servants, it fluctuates within 11 years, for administrative - within 9 years) [3].

The Presidential Decree 'On civil service’ of December 26, 1995, №2730, which has the effect of law, was the first document to set responsibilities of HR service. Nevertheless, the responsibilities of HR service were decreased with the formation of a body for civil service affairs in 1998 and adoption of the Law of the RK 'On civil service' in 1999. This reduction had a special effect on the procedures of competitive selection and attestation, which entailed limiting their independence in selecting personnel.

As a result, the law defines the responsibilities of HR services as follows: preparing a list of vacant jobs for submission to an authorized organization along with applications about vacant positions and other necessary data; documenting resolutions of a government agency concerning employees' service affiliation; keeping personal data files; making necessary notes in employees' work record books (track records); doing advisory work for civil servants on their legal status, control over observation of restrictions specified for civil servants; organizing (re)training and qualification upgrading courses for civil servants; recording civil servants' consent and acceptance of restrictions set by law (informing about consequences of violating the restrictions accepted) and other functions [4].

\section{Research in the field of civil service HR management system}

No specific normative legal act that defines the legal status of HR services as well as authorization of government agencies to solve the issues about status and responsibilities of HR services on their own have led to a considerable downgrading of the latter, e.g., selective research carried out in 29 government agencies displayed that only 3 government agencies (that makes up 10\% of the sum total) had HR departments in their organizational structure, in 9 government agencies they were represented in the form of HR offices ( $31 \%$ of the sum total). In the rest of the government agencies, the above-mentioned responsibilities were fulfilled by organizational, controlling or administrative departments.

Although most government agencies do not have a separate structural HR unit, the Regulations of their structural subdivisions have been analyzed with an aim to reveal how completely they set the objectives, tasks and regulations for their work with personnel. The analysis yielded that the norms provided by the documents duplicate the legislative norms and bylaws on civil service (personnel reserve, attestation, admission and service affiliation), specifying the recording, documenting and organizational functions of HR services.

A questionnaire survey was carried out, in which HR employees in central and local executive agencies participated, in order to analyze the situation with government agencies' HR services. The interviewees were $57 \mathrm{HR}$ employees of central executive agencies and 99 
of local executive agencies (located in regions). The regional coverage was built according to the principle: south-north, east-west, central. All in all, there were 156 respondents.

The survey showed that only $19,2 \%$ of the HR employees in central agencies and $12,2 \%$ in local executive agencies expressed their satisfaction with the powers and responsibilities they are delegated to in HR issues. Respectively, $50,9 \%$ and $66,6 \%$ of the employees in the given structural subdivisions were dissatisfied with the powers and responsibilities of HR services and the possibility to influence the situation in HR service of a government agency. $29,9 \%$ and $21,2 \%$ of the employees respectively found it difficult to answer the aforementioned question.

In Kazakhstan, the central role in civil service organizations belongs to the Agency of the Republic of Kazakhstan for Civil Service Affairs that is authorized within its framework of reference to implement a consistent public policy in civil service. Their framework of reference covers working out and adopting normative legal acts, within their jurisdiction, on issues of labour organization for civil servants; these documents are sent as directives to government agencies. At the same time, the HR employees of government agencies did not give a high evaluation for the normative legal and methodic maintenance of their work.

$50 \%$ and $37 \%$ of the HR employees of central and local executive agencies expressed their dissatisfaction with the level and quality of normative legal and methodic maintenance of their work. It should be noted that neither legislation has designated notions, such as 'HR service', 'HR service work', nor any other normative documents are available, such as regulations on HR service of government agencies, which would set its standard structure, staff size, functions, tasks and areas of focus.

The issue of HR specialists with an up-to-level training and appropriate employment term is urgent, e.g., $77 \%$ of the respondents had up to 3 years employment term in the given position. In addition, $36,2 \%$ of them specialized in law, $31,1 \%$ - in economics and $15,9 \%$ of the respondents had pedagogic educational background. The lack of specialists impacts the quality of HR services' work. The analysis of civil service law observation showed that government agencies most frequently violate the Rules of selective competition for vacant positions, attestation, order of service affiliation, imposition of disciplinary penalties, timely submission of a tax return on income and property.

Under the given circumstances, it is rather early to speak about the system of civil service HR management available, the one, which would ensure not only selection, but also professional development of staff on the basis of modern methods of HR assessment and planning civil servants' promotion, the most effective use of their professional and personal abilities and capabilities.

It is necessary to reform the system of HR services' work within government agencies in order to build up an effective system of civil service HR management - the necessity stressed by the Concept [5].

A significant step in this direction is the formation of HR service as an independent structural subdivision of government agencies. Founding the Service for HR management in central, territorial and oblast executive bodies is a vital and pressing issue. 


\section{Conclusions}

1. Overall, the research focused on the work of HR services of government agencies in two areas: external, i.e., within the organizational structure of a government agency, and internal, i.e., on the basis of qualitative and quantitative analysis of HR staff in government agencies, their labour organization.

2. Thus, the analysis of the situation and the findings of the questionnaire survey showed that at present HR service of government agencies in Kazakhstan needs radical changes rather than a slight improvement.

3. In this respect, the following measures should be taken into account in order to reform the HR service in Kazakhstan:

- to legislatively entrench precise standards of an appropriate 'general staff size: HR staff size' ratio of a government agency;

- to carry out activities targeted at improving HR services: working out consistent labour standards reflected in standard regulations, providing them with normative and methodic literature, training professional corps of efficient HR specialists;

- to consider issues about the use of special admission tests for job applicants and special qualification requirements for HR service managers.

Generally, the solution of the issues that have been presented in the research requires a scientific, methodic and advisory maintenance of the reforms in HR services.

\section{References}

1. Kazakhstan's Strategic Development Plan 2020.

2. Concept of Civil Service New Model of the Republic of Kazakhstan, July 21, 2011, №119.

3. Monitoring the Current State of Human Resources in Civil Service by the Agency of the Republic of Kazakhstan for Civil Service Affairs for January 1, 2012. In: Statistics, year.

4. On Civil Service. Law of the Republic of Kazakhstan, July 23 1999, №453.

5. Kaparov, S. G. Improving Civil Service in Kazakhstan: Monograph. Ekaterinburg, 2005.

6. Akchurin, A. and Abdina, A. Creating a Promotion System, Staff Selection and Deployment in the Civil Service of the Republic of Kazakhstan. Almaty: Centre for Social Issues Research, 2002.

7. Davletbayeva, Zh. Zh. Assessment of Civil Servants' Performance: Sociological Analysis. Dissertation for the degree of cand. in Sociology, 22.00.04. Astana, 2010. 


\title{
Alma Kuljambekova
}

\section{Žmogiškųjų išteklių tarnybų efektyvumo didinimas Kazachstano valstybinèse institucijose*}

\author{
Anotacija
}

Nauji žmogiškujų išteklių (toliau - ŽI) tarnybų iššūkiai apima ŽI politikos ịgyvendinimą ir ŽI vadybos koordinavimą vyriausybinèse agentūrose. ŽI tarnybos pradeda apimti vis platesnị veiklos spektrą, ịskaitant darbuotojų motyvacinių, skatinimo ir karjeros sistemų kūrimą, ŽI auditą vyriausybinèse agentūrose.

Didesnis vyriausybinių agentūrų efektyvumas, gyventojams teikiamų viešųų paslaugų kokybė ir valstybinių funkcijų ịgyvendinimas patenka ị visų su Kazachstano Respublikos valstybès tarnyba susijusių reformų dėmesio centrą. Reformų veiksmingumas priklauso nuo įvairių veiksnių ir sąlygų derinio. ŽI padalinys yra atsakingas už reformos igyvendinimą vietoje ir yra viena iš pagrindinių valdymo grandžių, užtikrinančių veiksmingą ir novatorišką vyriausybinės agentūros veiklą.

Alma Kuljambekova - Viešojo administravimo akademijos prie Kazachstano Respublikos Prezidento doktorantè, Astana, Kazachstanas.

E. paštas: alma@kyzmet.kz

Alma Kuljambekova, Academy of Public Administration under the President of the Republic of Kazakhstan, Ph.D. student.

E-mail: alma@kyzmet.kz

Straipsnis įteiktas redakcijai 2013 m. balandžio 13 d.; recenzuotas; parengtas spaudai 2013 m. spalio mèn.

* Pranešimas šio straipsnio tema buvo pateiktas elektroninèje konferencijoje „Viešasis administravimas centrineje Europoje: tradicijos paieškos“, organizuotoje Mykolo Romerio universiteto Viešojo administravimo instituto kartu su Akademine vadybos ir administravimo asociacija (AVADA) 2013 m. lapkričio 6-7 dienomis. 